\title{
Establishment of a first-line second-line treatment model for human pulmonary adenocarcinoma
}

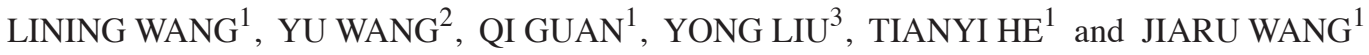 \\ ${ }^{1}$ Central Laboratory; ${ }^{2}$ Department of Laboratory; ${ }^{3}$ The 1 st Cardiology Department, \\ Central Hospital Affiliated To Shenyang Medical College, Shenyang, Liaoning 110024, P.R. China
}

Received November 25, 2015; Accepted September 22, 2016

DOI: 10.3892/ol.2016.5299

\begin{abstract}
Lung cancer is one of the most prevalent types of cancer in the world. Surgery, chemotherapy and radiotherapy are used clinically as treatments for numerous cancers. Due to the appearance of drug resistance, the remission rate is limited to $40-50 \%$. Docetaxel and pemetrexed are two drugs commonly used, and their effects in single-phase cell culture are well known. From the pharmacological point of view, it appears rational to hypothesize that sequential therapy effects can show better outcomes compared with traditional single-phase experiments. Considering this, the present study aimed to establish a first-line second-line adenocarcinoma treatment model, using the combination of cisplatin with docetaxel or pemetrexed in vitro in different sequential therapy timings. To test this, the human lung cancer A549 cell line was used. The inhibitory effect was determined by adding docetaxel following treatment with cisplatin and pemetrexed (Pem-Doc group) and comparing this with a group in which pemetrexed was added subsequent to treatment with cisplatin and docetaxel (Doc-Pem group). Additionally, the differences in the gene and protein expression levels of excision repair cross-completion gene 1 (ERCC1), a gene that promotes drug resistance to cisplatin, were compared between the two groups. The present results showed that the inhibitory effect of cell proliferation in the Pem-Doc group was increased compared with that of Doc-Pem group, while the gene expression and protein levels of ERCC1 in the Pem-Doc group were decreased compared with those of Doc-Pem group. The Pem-Doc treatment plan is more effective in inhibiting cell proliferation and in lowering the expression of the ERCC1 gene. Therefore, Pem-Doc may be a more effective adenocarcinoma treatment.
\end{abstract}

Correspondence to: Dr Lining Wang or Dr Qi Guan, Central Laboratory, Central Hospital Affiliated To Shenyang Medical College, 57th Southern Western Road, Tiexi, Shenyang, Liaoning 110024, P.R. China

E-mail:w111111jp@hotmail.com

E-mail: guanqi1231@sina.com

Key words: cisplatin, docetaxel, pemetrexed, non-small cell lung cancer, excision repair cross-completion gene 1

\section{Introduction}

Non-small cell lung cancer (NSCLC) accounts for $75-80 \%$ of all primary lung cancers. A cisplatin-based chemotherapy regimen has been the main solution for treating advanced NSCLC (1-4). Traditionally the first-line chemotherapy regimen includes cisplatin combined with another third-generation drug, such as docetaxel, paclitaxel or gemcitabine (5-9). For the second-line treatment, pemetrexed, docetaxel and target drugs are constantly used (10-14). The association between histology and a first-line regimen had not been studied until recently, with certain studies indicating that overall survival (OS) correlates with histological subtype. For example, a trial containing 1,725 patients showed that pemetrexed is suitable to be used for tumors with non-squamous histology, as an improved OS time was recorded compared with patients with squamous histology, who experienced a shorter survival time (15-17). Therefore, establishing a treatment model to mimic the first-line second-line treatment is important, as it can be used to confirm the known clinical trial information, to analyze the mechanism and to test other drugs in the future. The inhibitory effects of docetaxel and pemetrexed on cell proliferation have been demonstrated $(18,19)$. The present study compared the inhibitory effect of the docetaxel-pemetrexed (Doc-Pem) group with that of the pemetrexed-docetaxel (Pem-Doc) group. Due to certain factors, including the drug resistance of cisplatin during treatment, the remission rate is limited to $40-50 \%$. Excision repair cross-completion gene 1 (ERCC1) is one of the drug resistance genes, and it plays an important role in DNA repair (20). Overexpression of ERCC1 can cause drug resistance to cisplatin, and lowering the expression of ERCC1 in A549 cells can enhance the sensitivity to cisplatin $(21,22)$. The current study also detected if the combination plan can lower the expression of ERCC1.

\section{Materials and methods}

Materials. The materials used in the present study were as follows: Docetaxel (Shanghai Yuanye Bio-Technology Co., Ltd., Shanghai, China); pemetrexed (National Institutes for Food and Drug Control, Beijing, China); cisplatin (National Institutes for Food and Drug Control, Beijing, China); the A549 cell line (JRDUN Biotechnology, Shanghai, China); Hyclone RPMI 1640 media (GE Healthcare; Logan, UT, 
USA); fetal bovine serum (FBS; MRC, Jintan, Jiangsu, China); 0.25\% EDTA-trypsin (Beijing Leagene Biotechnology Co., Ltd., Beijing, China); CellTiter 96 Aqueous One Solution Cell Proliferation assay (Promega Corporation, Madison, WI, USA); TRIzol reagent (Invitrogen; Thermo Fisher Scientific, Inc., Waltham, MA, USA); RevertAid First Strand cDNA Synthesis kit (Thermo Fisher Scientific, Inc.); Real Time PCR Easy-SYBR Green I (Foregene Co., Ltd., Chengdu, Sichuan, China); primers (Shanghai Generay Biotech Co., Ltd., Shanghai, China); polyvinylidene difluoride (PVDF) membrane (EMD Millipore, Billerica, MA, USA); BCIP/NBT alkaline phosphatase color development kit (Beijing Huamaike Biotechnology, Beijing, China); and anti-ERCC1 (human) antibody, anti- $\beta$-actin (human) antibody and alkaline phosphatase-conjugated Affinipure Goat Anti-Rabbit IgG $(\mathrm{H}+\mathrm{L})$ antibody (Proteintech Group Inc., Rosemont, IL, USA).

Cell culture. A549 cells were cultured in RPMI 1640 medium containing $10 \% \mathrm{FBS}$, and kept in a $37^{\circ} \mathrm{C}$ incubator maintaining humidified air with $5 \% \mathrm{CO}_{2}$. When the cells reached $80-90 \%$ confluence, passaging was performed using $0.25 \%$ EDTA-trypsin.

Cell proliferation assay (CPA) to determine the half maximal inhibitory concentration $\left(I C_{50}\right)$. The cells were seeded in 96-well plates at a density of $2 \times 10^{4} / \mathrm{ml}(100 \mu 1$ per well), and were kept in a $37^{\circ} \mathrm{C}$ incubator maintaining humidified air with $5 \% \mathrm{CO}_{2}$. Subsequent to $24 \mathrm{~h}$, drugs at different concentrations were added (docetaxel, $0.2,0.3$ and $0.4 \mathrm{mg} / \mathrm{ml}$; pemetrexed, 0.4 , 0.8 and $1.6 \mathrm{mg} / \mathrm{ml}$; cisplatin, $0.265,0.53$ and $1.06 \mu \mathrm{g} / \mathrm{ml}$ ), with no addition to the blank group ( 3 wells per drug). Following incubation in a $37^{\circ} \mathrm{C}$ incubator for $72 \mathrm{~h}, 20 \mu \mathrm{l} \mathrm{CPA}$ solution was added. Subsequent to $2 \mathrm{~h}, 25 \mu \mathrm{l} 10 \% \mathrm{SDS}$ was added to stop the reaction. The optical density (OD) values were determined using a microplate reader (detection wave length, $492 \mathrm{~nm}$; reference wave length, $630 \mathrm{~nm}$; Multiskan MK3; Thermo Fisher Scientific, Inc.). The inhibition ratio was calculated as follows: Inhibition ratio $(100 \%)=\left(1-\mathrm{OD}_{\text {experimental }} / \mathrm{OD}_{\text {blank }}\right) \times 100$. Graphs were created showing the log-concentration vs. inhibition ratio, and the $\mathrm{IC}_{50}$ values were calculated.

CPA for combination with cisplatin in different sequential therapy timings. The cells were cultured as aforementioned and four groups were then created ( 3 wells per drug): $0.2 \mathrm{mg} / \mathrm{ml}$ docetaxel plus $0.62 \mu \mathrm{g} / \mathrm{ml}$ cisplatin was added to form the Doc-Pem group; $1.42 \mathrm{mg} / \mathrm{ml}$ pemetrexed plus $0.62 \mu \mathrm{g} / \mathrm{ml}$ cisplatin was added to form the Pem-Doc group; $0.62 \mu \mathrm{g} / \mathrm{ml}$ cisplatin only was added to form the DDP group; and no addition was made to form the blank group. All cultures were maintained in an incubator, and subsequent to $24 \mathrm{~h}$ (or $48 \mathrm{~h}$, 1st drug duration as shown in Table I) $1.42 \mathrm{mg} / \mathrm{ml}$ pemetrexed was added to the Doc-Pem group, and $0.2 \mathrm{mg} / \mathrm{ml}$ docetaxel was added to the Pem-Doc group. The medium was replaced for the DDP group and blank group, the incubation was continued for $24 \mathrm{~h}$ (or $48 \mathrm{~h}$, 2nd drug duration as shown in Table I), and the OD and inhibition ratio calculated as aforementioned.

Quantitative polymerase chain reaction ( $q P C R$ ). Cells of each group were collected and the total RNA was extracted using a TRIzol kit; the small amount of remaining genomic DNA was removed using DNase I (Beijing Huamaike Biotechnology, Beijing, China). The RNA quality was confirmed by Nanodrop spectrophotometry. Reverse transcription was performed as described in the manufacturer's instructions. Briefly, total RNA was mized with Random Hexamer primer $(1 \mu \mathrm{l})$, made up to a total volume of $12 \mu \mathrm{l}$ using nuclease-free water, and then $5 \mathrm{X}$ reaction buffer $(4 \mu \mathrm{l})$, Ribolock RNase Inhibitor $(1 \mu \mathrm{l}), 10 \mathrm{mM}$ dNTP mix $(2 \mu \mathrm{l})$ and RevertAid M-MuLV RT $(1 \mu \mathrm{l})$ were added. This was mixed gently and spun briefly, then incubated for $5 \mathrm{~min}$ at $25^{\circ} \mathrm{C}$, followed by $60 \mathrm{~min}$ at $42^{\circ} \mathrm{C}$. The reaction was terminated by heating at $70^{\circ} \mathrm{C}$ for $5 \mathrm{~min}$. The reverse transcription reaction products were stored at $-80^{\circ} \mathrm{C}$. $\mathrm{qPCR}$ was performed using the StepOne system normalized to a reference gene by the comparative $\mathrm{C}_{\mathrm{q}}$ method $\left(2^{-\Delta \Delta \mathrm{Cq}}\right)$ (23). The PCR was conducted using the Real Time PCR Easy SYBR Green kit (Foregene Co., Ltd.). The cycling conditions were $94^{\circ} \mathrm{C}$ for $3 \mathrm{~min}$, followed by 40 cycles at $94^{\circ} \mathrm{C}$ for $10 \mathrm{sec}, 65^{\circ} \mathrm{C}$ for $10 \mathrm{sec}$ and $72^{\circ} \mathrm{C}$ for $30 \mathrm{sec}$, the signal of amplified ERCC1 or $\beta$-actin was collected at the end of each cycle. The PCR mixture containing no template was used as a negative control. This qPCR experiment was repeated twice. The primers were as follows: ERCC1 forward, 5'-CTT GTC TTC TGG CTC GAA GG-3' and reverse, 5'-ACT CAG GAG GCA GTG AAT GG-3'; $\beta$-actin forward, 5'-CAT CGT CCA CCG CAA ATG CTTC-3' and reverse, 5'-AAC CGA CTG CTG TCA CCT TCA C-3'.

Western blot analysis. Cells of each group were collected (cells from five 10-cm dishes per group), and 1/4 volume of $5 \mathrm{X}$ loading buffer was added. The cells were subjected to $98^{\circ} \mathrm{C}$ denaturation for $5 \mathrm{~min}$, prior to separation by $10 \%$ SDS-PAGE. The proteins were transferred to a PVDF membrane by the semi-dry method, and were blocked for $30 \mathrm{~min}$ by $5 \%$ skimmed milk. The primary antibodies anti-ERCC1 (Proteintech Group Inc.; catalog no. 14586-1-AP; dilution, 1:300) and anti- $\beta$-actin (Proteintech Group Inc.; catalog no, 20536-1-AP; dilution, 1:500) were added, and the sheets were incubated at $4^{\circ} \mathrm{C}$ overnight, prior to being washed by Tris-buffered saline with Tween-20 (TBST) 4 times, for 5 min each. The ALP-conjugated Affinipure Goat Anti-Rabbit $\operatorname{IgG}(\mathrm{H}+\mathrm{L})$ secondary antibody (Proteintech Group Inc.; catalog no. SA00002-2; dilution, 1/500) was then added and incubated at room temperature for $1 \mathrm{~h}$, prior to being washed by TBST 4 times, for 5 min each. The color was developed with a BCIP/NBT kit. The bands were analyzed by ImageJ software (National Institutes of Health, Bethesda, MD, USA) and the ERCC1/ $\beta$-actin ratios were calculated using ImageJ software (National Institutes of Health, Bethesda, MD, USA) to measure the grayscale value of each band.

Statistical analysis. All analyses were performed with the Statistical Package for the Social Sciences version 22 (IMB SPSS, Armonk, NY, USA). One-wayanalysis of variance and the least significant difference test were used to evaluate the differences between groups. $\mathrm{P}<0.05$ was considered to indicate a statistically significant difference.

\section{Results}

Inhibitory effect on cell proliferation is stronger in the Pem-Doc group. The CPA (Fig. 1) showed that all 3 drugs, including docetaxel, pemetrexed and cisplatin, could inhibit 
Table I. Duration of drug treatment in 4 methods.

\begin{tabular}{lll}
\hline Method 1 st drug regime and duration & 2nd drug regime and duration & Change to fresh media \\
\hline 1 & Doc + DDP for $24 \mathrm{~h}$ & Pem for $24 \mathrm{~h}$ \\
& Pem + DDP for $24 \mathrm{~h}$ & Doc for $24 \mathrm{~h}$ \\
DDP for $24 \mathrm{~h}$ & Blank for $24 \mathrm{~h}$ \\
& Blank for $24 \mathrm{~h}$ & Blank for $24 \mathrm{~h}$ \\
& Doc + DDP for $24 \mathrm{~h}$ & Pem for $24 \mathrm{~h}$ \\
& Pem + DDP for $24 \mathrm{~h}$ & Doc for $24 \mathrm{~h}$ \\
& DDP for $24 \mathrm{~h}$ & Blank for $24 \mathrm{~h}$ \\
& Blank for $24 \mathrm{~h}$ & Blank for $24 \mathrm{~h}$ \\
& Doc + DDP for $48 \mathrm{~h}$ & Pem for $24 \mathrm{~h}$ \\
& Pem + DDP for $48 \mathrm{~h}$ & Doc for $24 \mathrm{~h}$ \\
& DDP for $48 \mathrm{~h}$ & Blank for $24 \mathrm{~h}$ \\
& Blank for $48 \mathrm{~h}$ & Blank for $24 \mathrm{~h}$ \\
& Doc + DDP for $24 \mathrm{~h}$ & Pem for $48 \mathrm{~h}$ \\
Pem + DDP for $24 \mathrm{~h}$ & Doc for $48 \mathrm{~h}$ \\
DDP for $24 \mathrm{~h}$ & Blank for $48 \mathrm{~h}$ \\
Blank for $24 \mathrm{~h}$ & Blank for $48 \mathrm{~h}$
\end{tabular}

Doc, docetaxel; Pem, pemetrexed; DDP, cisplatin.

\begin{tabular}{|rrr|}
\hline Docetaxel & - Pemetrexed & Cisplatin \\
- Docetaxel & --- Pemetrexed & -- Cisplatin \\
\hline
\end{tabular}

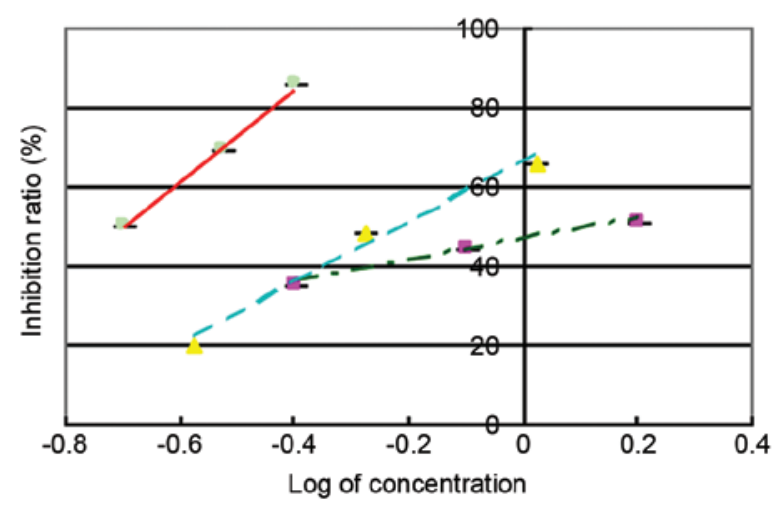

Figure 1. Inhibitory effect of A549 cells by cell proliferation assay with the addition of three drugs. X-axis, log of concentration of each drug; Y-axis, inhibition ratio compared with the blank group (without the addition of drugs). The inhibition ratio increased with the increase in drug concentration.

the proliferation of the cells; this inhibitory effect became stronger with increased drug concentration. The $\mathrm{IC}_{50}$ of docetaxel was $0.2 \mathrm{mg} / \mathrm{ml}$, the $\mathrm{IC}_{50}$ of pemetrexed was $1.42 \mathrm{mg} / \mathrm{ml}$ and the $\mathrm{IC}_{50}$ of cisplatin was $0.62 \mu \mathrm{g} / \mathrm{ml}$. To test the effect of sequential combination, four methods were tested (Table I). The results (Fig. 2) show that in method 1, the inhibition ratio of the Pem-Doc group (60.3\%) and that of the Doc-Pem group (54.2\%) was increased compared with that of the DDP group $(38.1 \%)$ (both $\mathrm{P}<0.001)$. Additionally, the Pem-Doc group was significantly increased compared with the Doc-Pem group $(\mathrm{P}=0.020)$. In methods 2,3 and 4 , the

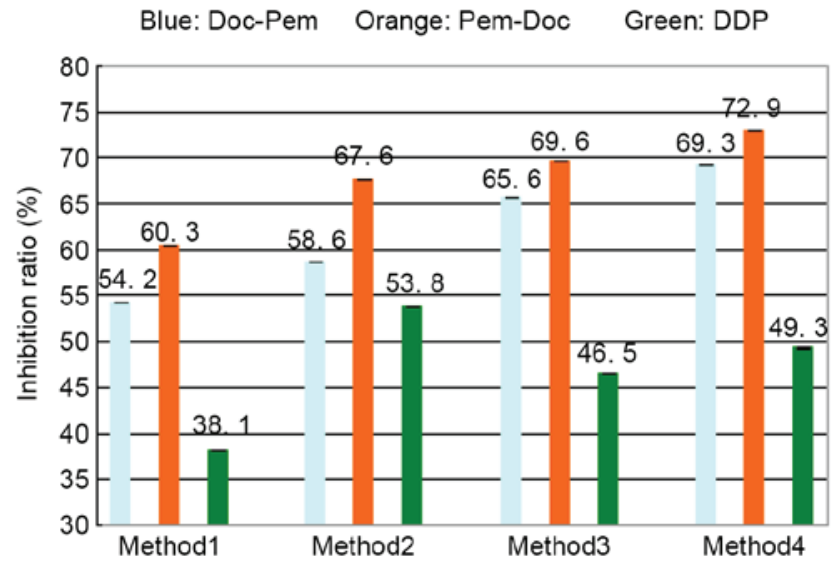

Figure 2. Inhibition ratios of 4 groups using 4 methods, as determined by cell proliferation assay. The 4 methods differ by duration time in the 1 st and 2 nd stages, as shown in Table I. Doc, docetaxel; Pem, pemetrexed; DDP, cisplatin.

inhibition ratio of the Pem-Doc group and the Doc-Pem group was increased compared with that of the DDP group $(\mathrm{P}<0.001$, $\mathrm{P}=0.002, \mathrm{P}<0.001, \mathrm{P}<0.001, \mathrm{P}<0.001$ and $\mathrm{P}<0.001$, respectively), and there were significant differences between the Pem-Doc group and the Doc-Pem group $(\mathrm{P}<0.001, \mathrm{P}=0.040$ and $\mathrm{P}=0.040$, respectively). This indicated that the inhibitory effect on cell proliferation in the Pem-Doc group was stronger compared with that of the Doc-Pem group; furthermore, this tendency was not affected by the different treatment duration of the drugs.

ERCCl gene expression in the Pem-Doc group is lower than that in the Doc-Pem group. To investigate the association between the inhibitory effects of two regimes on the cell proliferation and drug resistance of cisplatin, ERCC1, a drug 

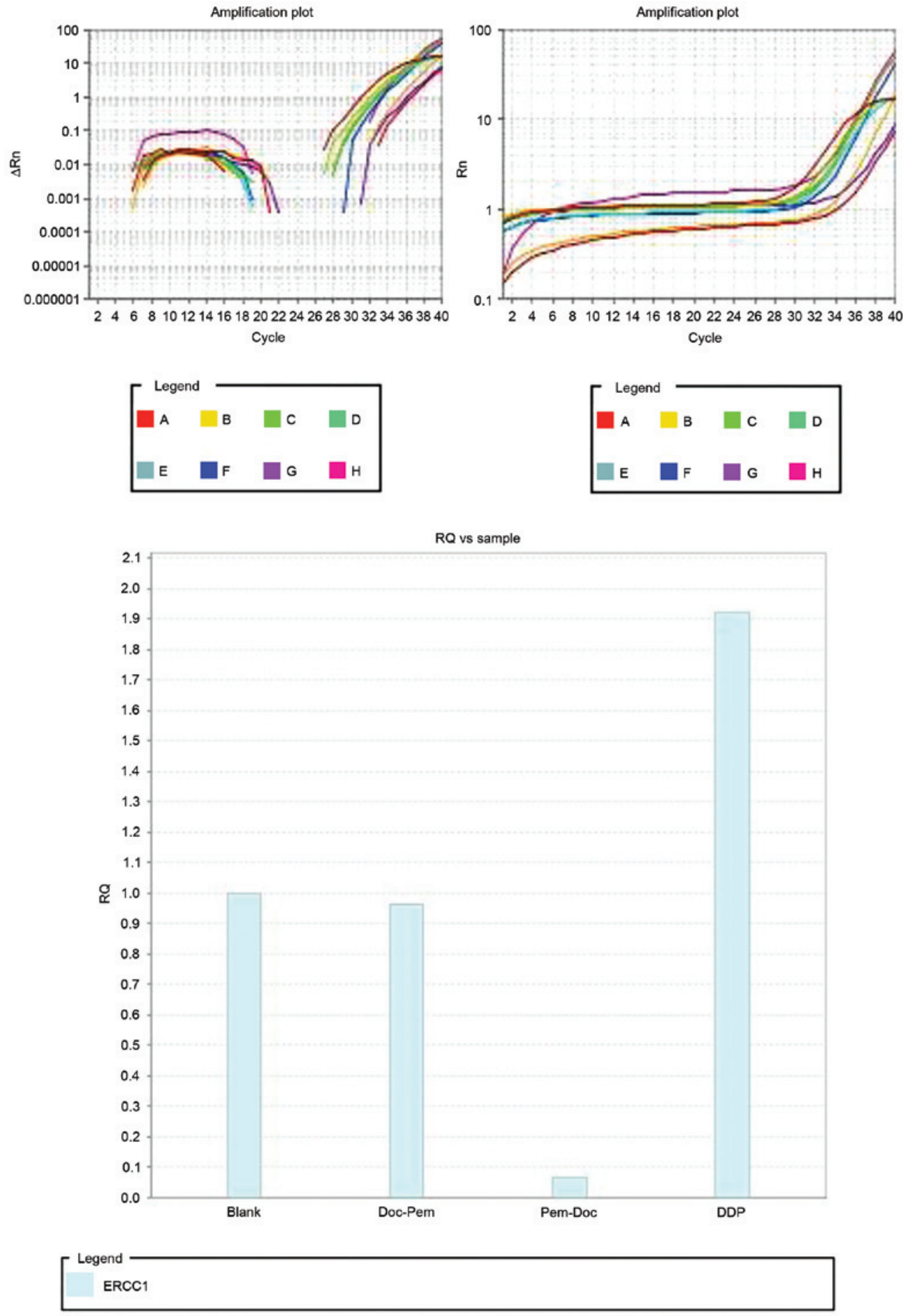

Figure 3. Expression of ERCC1 by quantitative polymerase chain reaction. The internal control was $\beta$-actin. A to $\mathrm{H}$ represent the samples in row A (numbers 1 to 12 ) to row $\mathrm{H}$ (numbers 1 to 12), respectively (A1, ERCC1 primers, no template; B1, actin primers, no template; $\mathrm{C} 1, \mathrm{ERCC} 1$ primers, template from blank group; D1, actin primers, template from blank group; E1, ERCC1 primers, template from Doc-Pem group; F1, actin primers, template from Doc-Pem group; G1, ERCC1 primers, template from Pem-Doc group; H1, actin primers, template from Pem-Doc group; A2, ERCC1 primers, template from DDP group; B2, actin primers, template from DDP group. Blank, without addition of drugs in the 1st and 2nd stages; RQ, relative quantification; Rn, normalized reporter (fluorescence of the reporter dye divided by the fluorescence of a passive reference dye (ROX)]; $\Delta \mathrm{Rn}, \mathrm{Rn}$ minus the baseline.

resistance gene, was studied by qPCR, with $\beta$-actin as the internal control. qPCR (Fig. 3) showed that the expression of the ERCC1 gene in the DDP group was $~ 1.9$ times that of the blank group (without the addition of drugs). The expression in the Doc-Pem group was slightly decreased compared with that of the blank group, while the expression in the Pem-Doc group was 0.066 times that of the blank group. This indicates that the
Pem-Doc plan may increase the inhibitory effect by inhibiting the expression of ERCC1.

Pem-Doc group inhibits the expression of the ERCC1 protein more efficiently. To obtain further information on ERCC1 expression, cells from 4 groups underwent western blotting. The result (Fig. 4) show that the DDP group $(0.62 \mu \mathrm{g} / \mathrm{ml})$ 

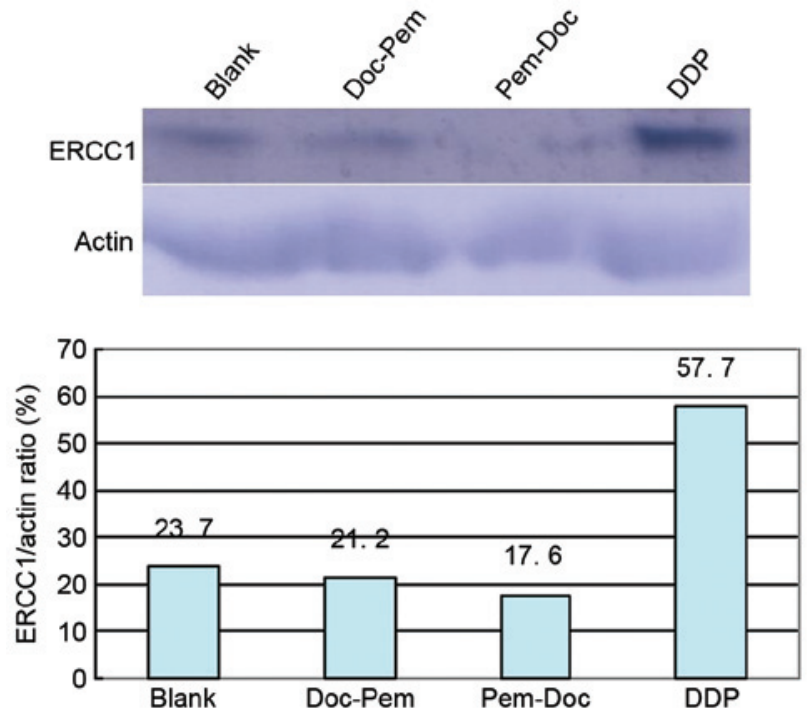

Figure 4. Expression of ERCC1 by western blot analysis. Internal control, $\beta$-actin. The grayscale values of each band were analyzed using ImageJ software.

markedly promoted the expression of the ERCC1 protein; the ERCC1/ $\beta$-actin ratio was $57.7 \%$, which was 2.4 times that of the blank group. The values of the combination groups were lower than that of blank group; the value in the Doc-Pem group was 0.89 times that of the blank group, while it was 0.74 times that of the blank group in the Pem-Doc group. This indicates that the Pem-Doc plan may have a better inhibitory effect through inhibiting the expression of the ERCC1 protein.

\section{Discussion}

Docetaxel promotes microtubule polymerization and inhibits depolymerization, which results in the death of cancer cells. The combination of docetaxel with cisplatin is constantly used in the clinic, and patients with non-small cell lung cancer can benefit from the prolongation of survival $(7,10,14)$. Pemetrexed is a novel drug that can inhibit the metabolism of folic acid by inhibiting the activity of required enzymes, including thymidylate, dihydrofolate reductase and phosphoribosyl glycinamide transtormylase (17). This process results in abnormalities in folic acid metabolism and nucleotide synthesis, which leads to the death of cancer cells. In a large trial containing 571 patients (12), results showed that pemetrexed had the same effect as docetaxel in treating patients with advanced stage NSCLC. Additionally, fewer side effects were observed and pemetrexed may therefore be a useful drug for second-line treatment. In 2004, pemetrexed was approved for use as a second-line treatment. In previous years, it was reported that the combination of pemetrexed with cisplatin was well tolerated and was the approved standard first-line therapy $(24,25)$. Although pemetrexed is an ineffective drug for squamous carcinomas, it has been found to be effective in non-squamous NSCLC (15-17). Adenocarcinoma is a non-squamous subtype that accounts for $\sim 50 \%$ of lung cancer cases. The inhibitory effect of chemical drugs on cell proliferation have been researched widely $(21,22)$, and the present study was designed to establish an adenocarcinoma treatment model, which includes the combination of cisplatin with docetaxel or pemetrexed in vitro in different sequential therapy timings, so that the effect and mechanism could be studied. The present model can be used to test other drugs, and to compare the effect against the Pem-Doc group, which acts as a control.

The present results showed that the inhibitory effect of the combination groups (Doc-Pem and Pem-Doc groups) was stronger than that of the DDP group. Among the combination groups, the effect in the Pem-Doc group was stronger compared with that in the Doc-Pem group. Furthermore, the tendency did not change with different treatment durations $(24 \rightarrow 24 \mathrm{~h}$; $48 \rightarrow 24 \mathrm{~h} ; 24 \rightarrow 48 \mathrm{~h}$ ). The drug resistance of cisplatin is an important affecting factor in chemotherapy, qPCR showed that the expression of the ERCC1 gene in the Pem-Doc group was inhibited compared with that of the Doc-Pem group, and the same pattern was identified for the protein level by western blot analysis. This indicated that Pem-Doc plan may increase the inhibitory effect more efficiently by inhibiting the expression of ERCC1, thus lowering the drug resistance of cisplatin.

\section{Acknowledgements}

The present study was supported a grant from Shenyang Medical College for the Returned Overseas Chinese Scholars of Lining Wang (no. 20144062).

\section{References}

1. Takita H, Edgerton F, Marabella P, Conway D and Harguindey S: Platinum-based combination chemotherapy in non-small cell lung carcinoma. Cancer 48: 1528-1530, 1981 .

2. Belani CP: Docetaxel in combination with platinums in patients with advanced non-small-cell lung cancer. Oncology (Williston Park) 11 (8 Suppl 8): S42-S45, 1997.

3. Stinchcombe TE, Borghaei H, Barker SS, Treat JA and Obasaju C: Pemetrexed with platinum combination as a backbone for targeted therapy in non-small-cell lung cancer. Clin Lung Cancer 17: 1-9, 2016.

4. Al-Farsi A and Ellis PM: Treatment paradigms for patients with metastatic non-small cell lung cancer, squamous lung cancer: First, second, and third-line. Front Oncol 4: 157, 2014.

5. Gatzemeier U, von Pawel J, Gottfried M, ten Velde GP, Mattson K, de Marinis F, Harper P, Salvati F, Robinet G, Lucenti A, et al: Phase III comparative study of high-dose cisplatin versus a combination of paclitaxel and cisplatin in patients with advanced non-small cell lung cancer. J Clin Oncol 18: 3390-3399, 2000.

6. Scagliotti GV, De Marinis F, Rinaldi M, Crinò L, Gridelli C, Ricci S, Matano E, Boni C, Marangolo M, Failla G, et al: Phase III randomized trial comparing three platinum-based doublets in advanced non-small-cell lung cancer. J Clin Oncol 20: 4285-4291, 2002.

7. Schiller JH, Harrington D, Belani CP, Langer C, Sandler A, Krook J, Zhu J and Johnson DH; Eastern Cooperative Oncology Group: Comparison of four chemotherapy regimens for advanced non-small-cell lung cancer. N Engl J Med 346: 92-98, 2002.

8. Smit EF, van Meerbeeck JP, Lianes P, Debruyne C, Legrand C, Schramel F, Smit H, Gaafar R, Biesma B, Manegold C, et al: Three-arm randomized study of two cisplatin-based regimens and paclitaxel plus gemcitabine in advanced non-small-cell lung cancer: A phase III trial of the European organisation for research and treatment of cancer lung cancer group-EORTC 08975. J Clin Oncol 21: 3909-3917, 2003.

9. Fossella F, Pereira JR, von Pawel J, Pluzanska A, Gorbounova V, Kaukel E, Mattson KV, Ramlau R, Szczesna A, Fidias P, et al: Randomized, multinational, phase III study of docetaxel plus platinum combination versus vinorelbine plus cisplatin for advanced non-small-cell lung cancer: The TAX 326 study group. J Clin Oncol 21: 3016-3024, 2003. 
10. Shepherd FA, Dancey J, Ramlau R, Mattson K, Gralla R, O'Rourke M, Levitan N, Gressot L, Vincent M, Burkes R, et al: Prospective randomized trial of docetaxel versus best supportive care in patients with non-small-cell lung cancer previously treated with platinum-based chemotherapy. J Clin Oncol 18 2095-2103, 2000.

11. Fossella FV, DeVore R, Kerr RN, Crawford J, Natale RR, Dunphy F, Kalman L, Miller V, Lee JS, Moore M, et al: Randomized phase III trial of docetaxel versus vinorelbine or ifosfamide in patients with advanced non-small-cell lung cancer previously treated with platinum-containing chemotherapy regimens. The TAX 320 Non-Small cell lung cancer study group. J Clin Oncol 18: 2354-2362, 2000

12. Hanna N, Shepherd FA, Fossella FV, Pereira JR, De Marinis F, von Pawel J, Gatzemeier U, Tsao TC, Pless M, Muller T, et al: Randomized phase 111 trial of pemetrexed versus doeetaxel in patients with non-small-cell lung cancer previously treated with chemotherapy. J Clin Onco1 22: 1589-1597, 2004.

13. Shepherd FA, Rodrigues Pereira J, Ciuleanu T, Tan EH, Hirsh V, Thongprasert S, Campos D, Maoleekoonpiroj S, Smylie M, Martins R, et al: Erlotinib in previously treated non-small-cell lung cancer. N Engl J Med 353: 123-132, 2005.

14. Di Maio M, Perrone F, Chiodini P, Gallo C, Camps C, Schuette W, Quoix E, Tsai CM and Gridelli C: Individual patient data meta-analysis of docetaxel administered once every 3 weeks compared with once every week second-line treatment of advanced non-small-cell lung cancer. J Clin Oncol 25: 1377-1382, 2007.

15. Peterson P, Park K, Fossella F, Gatzemeier U, John W and Scagliotti GV: Is pemetrexed more effective in adenocarcinoma and large cell lung cancer than in squamous cell carcinoma? A retrospective analysis of a phase III trial of pemetrexed vs docetaxel in previously treated patients with advanced non-small cell lung cancer (NSCLC). J Thorac Oncol 2 (Suppl 4): s851, 2007.

16. Scagliotti GV, Parikh P, von Pawel J, Biesma B, Vansteenkiste J, Manegold C, Serwatowski P, Gatzemeier U, Digumarti R, Zukin M, et al: Phase III study comparing cisplatin plus gemcitabine with cisplatin plus pemetrexed in chemotherapy-naive patients with advanced-stage non-small-cell lung cancer. J Clin Oncol 26: 3543-3551, 2008.
17. Scagliotti G, Hanna N, Fossella F, Sugarman K, Blatter J, Peterson P, Simms L and Shepherd FA: The differential efficacy of pemetrexed according to NSCLC histology: A review of two phase III studies. Oncologist 14: 253-263, 2009.

18. Zhang QC, Jiang SJ, Zhang S and Ma XB: Histone deacetylase inhibitor trichostatin A enhances antitumor effects of docetaxel or erlotinib in A549 cell line. Asian Pac J Cancer Prev 13: 3471-3476, 2012.

19. Wu DM, Zhang P, Xu GC, Tong AP, Zhou C, Lang JY and Wang CT: Pemetrexed induces G1 phase arrest and apoptosis through inhibiting Akt activation in human non small lung cancer cell line A549. Asian Pac J Cancer Prev 16: 1507-1513, 2015.

20. Tsai MS, Weng SH, Chen HJ, Chiu YF, Huang YC, Tseng SC, Kuo YH and Lin YW: Inhibition of p38 MAPK-dependent excision repair cross-complementing 1 expression decreases the DNA repair capacity to sensitize lung cancer cells to etoposide. Mol Cancer Ther 11: 561-571, 2012.

21. Liu YP, Ling Y, Qi QF, Zhang YP, Zhang CS, Zhu CT, Wang MH and Pan YD: The effects of ERCC1 expression levels on the chemosensitivity of gastric cancer cells to platinum agents and survival in gastric cancer patients treated with oxaliplatin-based adjuvant chemotherapy. Oncol Lett 5: 935-942, 2013.

22. Cai Y, Yan X, Zhang G, Zhao W and Jiao S: The predictive value of ERCC1 and p53 for the effect of panobinostat and cisplatin combination treatment in NSCLC. Oncotarget 6: 18997-19005, 2015.

23. Livak KJ and Schmittgen TD: Analysis of relative gene expression data using real-time quantitative PCR and the 2(-Delta Delta C(T)) method. Methods 25: 402-408, 2001.

24. Fleeman N, Bagust A, McLeod C, Greenhalgh J, Boland A, Dundar Y, Dickson R, Tudur Smith C, Davis H, Green J and Pearson M: Pemetrexed for the first-line treatment of locally advanced or metastatic non-small cell lung cancer. Health Technol Assess 14 (Suppl 1): S47-S53, 2010.

25. Pereira JR, Cheng R, Orlando M, Kim JH and Barraclough H: Elderly subset analysis of randomized phase III study comparing pemetrexed plus carboplatin with docetaxel plus carboplatin as first-line treatment for patients with locally advanced or metastatic non-small cell lung cancer. Drugs $\mathrm{R}$ D 13: 289-296, 2013. 